\title{
The Effect of Heat Treatments and Drip Line Placements on The Yield and Quality of Garlic ${ }^{+}$
}

\author{
Alina Djanie ${ }^{1, *}$, Stephen Harper ${ }^{2}$ and Robyn Cave ${ }^{1}$ \\ 1 School of Agriculture and Food Sciences, The University of Queensland, Gatton 4343, Australia; \\ alinadjanie@gmail.com (A.D.); r.cave@uq.edu.au (R.C.) \\ 2 The Department of Agriculture and Fisheries, Gatton, Australia; Stephen.Harper@daf.qld.gov.au \\ * Correspondence: alinadjanie@gmail.com \\ + Presented at the third International Tropical Agriculture Conference (TROPAG 2019), Brisbane, Australia, \\ 11-13 November 2019.
}

Published: 7 March 2020

\begin{abstract}
Despite garlic being a crop with significant economic value, the plant has severe productivity constraints and challenges that contribute to low yield and quality. One of the main difficulties in garlic production is Fusarium basal rot (FBR) caused by Fusarium oxysporum formae speciales cepae (FOC). The soil-borne fungus infects the roots and basal plates of alliums causing delayed emergence and bulb rot at pre- and postharvest stages. The incidence of the pathogen is increasing and is expected to increase further due to growth being promoted under warmer temperatures associated with climate change. Management of the pathogen is difficult because it produces chlamydospores that can survive for years in the soil. Potential practices for reducing FBR in garlic are hot water or dry heat treatments applied to cloves at $50^{\circ} \mathrm{C}$ or $45^{\circ} \mathrm{C}$, respectively, for $30 \mathrm{~min}$ prior to planting, and controlling irrigation using single or double drip line placement for $1.5 \mathrm{~m}$ wide beds with two rows of garlic. The current study investigated the impact of controlled irrigation on FBR prevalence. These chemical-free practices are relatively easy to apply and could be effective for managing FBR in conventional and organic grown garlic.
\end{abstract}

Keywords: Fusarium basal rot; Chlamydosphores; dripline placement

Funding: This research received no external funding.

Acknowledgments: I am grateful to my supervisors; Robyn Cave and Stephen Harper for their guidance throughout this research. Thanks to the staff at DAF for their assistance with agronomic practices on the field and to Lachlan Fowler for helping me with my heat treatments.

Conflicts of Interest: The author declares no conflict of interest.

(C) 2020 by the authors. Licensee MDPI, Basel, Switzerland. This article is an open access article distributed under the terms and conditions of the Creative Commons Attribution (CC BY) license (http://creativecommons.org/licenses/by/4.0/). 